\title{
Trombolytisk behandling og trombektomi ved ukjent slagdebut
}
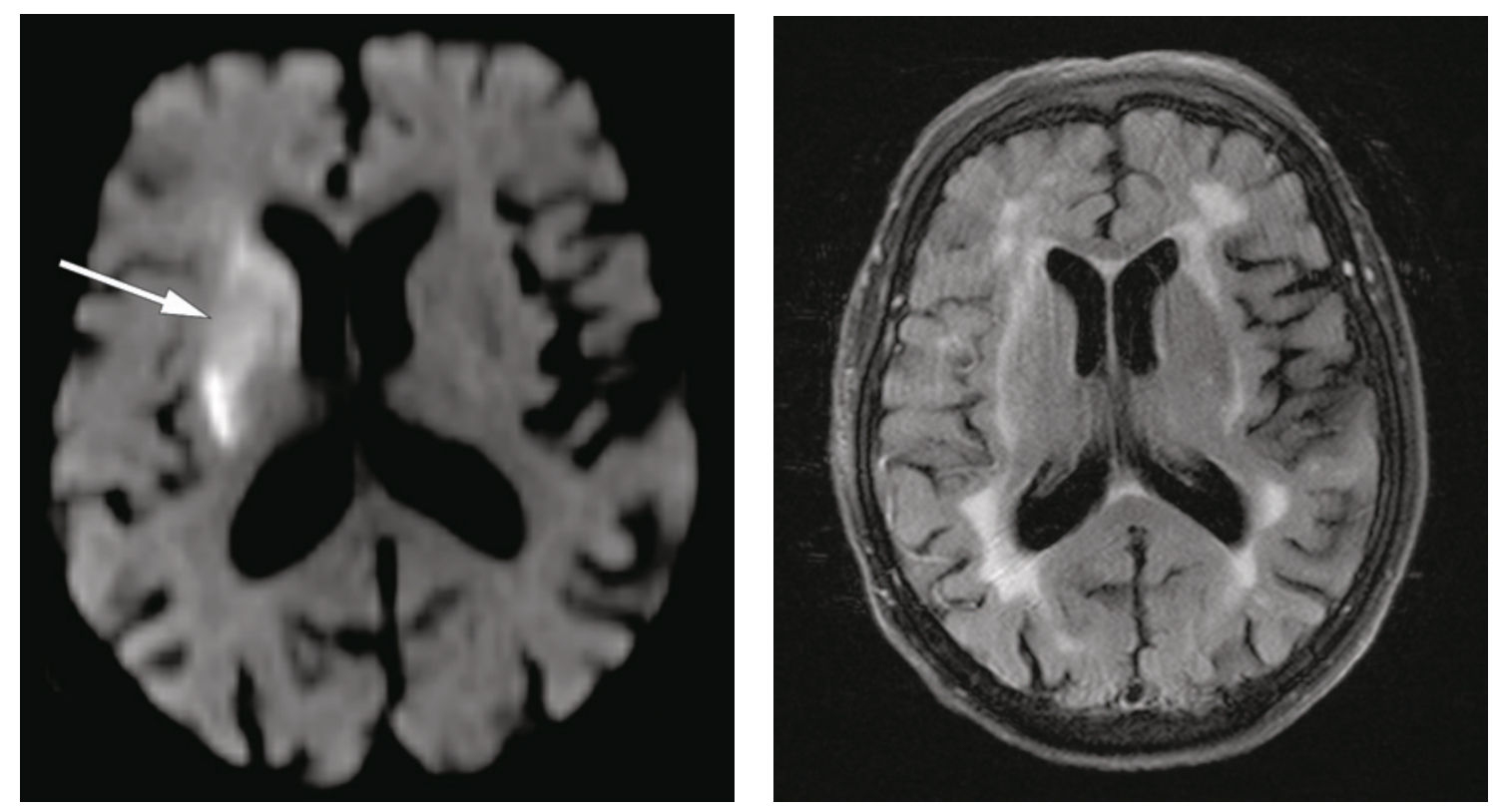

Kan man gi trombolytisk behandling eller utføre trombektomi hvis pasienten våkner med slagsymptomer? Opptil en firedel av alle hjerneinfarkt skjer under søvn, men trombolytisk behandling er kontraindisert hvis det har gått mer enn 4,5 timer fra symptomdebut (1).

En kvinne i 80-årene våknet med lammelse i venstre side av kroppen. Hun ble innlagt i akuttmottak klokken 0820, hvor man fant uttalt hemiparese med sentral facialisparese og neglekt på venstre side. NIHSS-skår var 17. En NIHSS-skår (National Institute of Health Stroke Scale) på $\geq 15$ blir regnet som et alvorlig hjerneslag.

Pasienten hadde våknet med symptomene klokken 0625, og symptomdebut var ukjent. Det ble utført MR-caput etter oppvåkningsslag-protokoll («wake-up stroke») (DWI- og FLAIR-sekvens). Diffusjonsvektede bilder viste diffusjonsrestriksjon i høyre basalganglieregion og corona radiata (fig 1) med korrelerende lavsignal på ADC-kartet. FLAIRsekvensen viste ingen sikre signalavvik i det affiserte området (fig 2). Dette tydet på at infarktforandringene var ferske, og klokken 0850 ble det derfor gitt intravenøs trombolytisk behandling. Etter at trombolytisk behandling var satt i gang ble det utført CTangiografi av pre- og intracerebrale kar, som viste en okklusjon i proksimale del av arteria cerebri media (ACM) på høyre side. Pasienten ble raskt overflyttet til angiografilaben hvor det klokken 0940 ble igangsatt trombektomi, som var teknisk vellykket.
Pasientens kliniske tilstand forbedret seg dramatisk, og hun ble utskrevet fire dager senere, med kun en lettgradig venstresidig hemiparese. NIHSS-skår var 2. Årsaken til hjerneinfarktet var atrieflimmer.

I dette tilfellet hadde man holdepunkter for at symptomene hadde startet innenfor trombolysegrensen på 4,5 timer, siden MR-undersøkelse viste iskemi på de diffusjonsvektede bildene, mens FLAIR-sekvensen ikke viste korrelerende signalavvik (diffusion-flair-mismatch). Rask diagnostikk bidro til at man kunne gi trombolytisk behandling og trombektomi, noe som trolig førte til et godt utfall for denne pasienten. Studier viser lovende resultater ved å identifisere de riktige pasientene for trombolytisk behandling, med bruk av MR etter oppvåkningsslagprotokoll (2).

Pasienten har gitt samtykke til at artikkelen blir publisert.

\section{Christopher Elnan Kvistad}

echr@helse-bergen.no

Øivind Torkildsen

Halvor Næss

Nevrologisk avdeling

Haukeland universitetssykehus

\section{Sigurd Svalestad}

Radiologisk avdeling

Haukeland universitetssykehus
Christopher Elnan Kvistad (f. 1982) er ph.d. og lege i spesialisering i nevrologi.

Forfatter har fylt ut ICMJE-skjemaet og oppgir ingen interessekonflikter.

Øivind Torkildsen (f. 1979) er ph.d., spesialist i nevrologi, overlege og professor.

Forfatter har fylt ut ICMJE-skjemaet og oppgir ingen interessekonflikter.

Halvor Næss (f. 1957) er ph.d., spesialist i nevrologi og indremedisin, overlege og professor. Forfatter har fylt ut ICMJE-skjemaet og oppgir ingen interessekonflikter.

Sigurd Svalestad (f. 1973) er spesialist i radiologi og overlege.

Forfatter har fylt ut ICMJE-skjemaet og oppgir ingen interessekonflikter.

\section{Litteratur \\ 1. Thomalla G, Cheng B, Ebinger M et al. DWI-FLAIR mismatch for the identification of patients with acute ischaemic stroke within $4.5 \mathrm{~h}$ of symptom onset (PRE-FLAIR): a multicentre observational study. Lancet Neurol 2011; 10: 978-86. \\ 2. Thomalla G. Gerloff C. Treatment concepts for wake-up stroke and stroke with unknown time of symptom onset. Stroke 2015; 46: 2707-13.}

Mottatt 29.3. 2016, første revisjon innsendt 3.6. 2016, godkjent 1.7. 2016. Redaktør: Martine Rostadmo.

> Se også artikkel side 1333 